\title{
Coronavirus-associated Antibodies in Nasopharyngeal Carcinoma and Infectious Mononucleosis*
}

\author{
W. Arnold ${ }^{1}$, M. Klein ${ }^{2}$, J. B. Wang ${ }^{1}$, W. A. K. Schmidt ${ }^{2}$, \\ and H. J. Trampisch ${ }^{3}$ \\ ${ }^{1}$ Dept. of Otorhinolaryngology (Chairman: Prof. K. H. Vosteen, MD), \\ ${ }^{2}$ Institute for Medical Microbiology and Virology (Chairman: Prof. P. Naumann, MD), \\ ${ }^{3}$ Institute for Medical Statistics and Biomathematics (Chairman: Prof. H. J. Jesdinsky, MD), \\ University of Düsseldorf, \\ Moorenstraße 5, D-4000 Düsseldorf 1, Federal Republic of Germany
}

\section{Antikörper gegen Coronaviren beim Nasopharynxkarzinom und bei der infektiösen Mononukleose}

Zusammenfassung. Coronavirusähnliche cytoplasmatische Einschlüsse waren in Tumorzellen des Nasopharynxkarzinoms, seiner Metastase und nach Transplantation auf die nackte Maus elektronenoptisch gefunden worden. Zur immunofluoreszenzmikroskopischen Darstellung der Coronaviren wurden Zellkulturen aus menschlichen Trachealepithelien benutzt, die mit einem bekannten Stamm von Coronaviren infiziert wurden. Die infizierten Zellkulturen dienten als bekanntes Antigen, an dem mittels des indirekten Immunfluoreszenztestes 83 Kontrollseren, 73 Seren von NPC-Patienten und 40 Seren von Patienten mit gesicherter Mononucleose ausgetestet wurden. Es ließ sich eindeutig nachweisen, daß Patienten mit NPC oder IM einen signifikant höheren Antikörpertiter im Serum besitzen als gesunde Vergleichspersonen oder Patienten mit anderen Erkrankungen. Ferner benützten wir vom Kaninchen stammende Anti-Corona-Antikörper, um an der Tumorzelle des NPC die ausschließliche cytoplasmatische Lokalisation des Antigens nachzuweisen. Während beim EBNA-Test zum Nachweis der kerngebundenen Epstein-Barr-Antigene ausschließlich die Tumorzellkerne fluoreszieren, leuchten in den Tupfpräparaten des gleichen Tumormaterials beim Coronatest nur die cytoplasmatischen Zellanteile. Die Untersuchungen deuten an, daß beim Nasopharynxkarzinom und bei der infektiösen Mononucleose neben der bekannten Epstein-Barr-Virusinfektion (DNS-Viren) auch eine RNS-Virusinfektion (Coronaviren) eine Rolle spielen können.

Schlüsselwörter: Coronavirusspezifische Antikörper im Serum von NPC-Kranken und bei Mononukleose - Positive Immunofluoreszenz auf

\footnotetext{
* Supported by the Deutsche Forschungsgemeinschaft, grant no. Ar 120

Offprint requests to: W. Arnold, MD, Dept. of Otorhinolaryngology, Klinikum Großhadern, Marchioninistraße 15, D-8000 Munich 70, Federal Republic of Germany
} 
Coronaviren im Cytoplasma von NPC-Tumorzellen - Statistische Auswertung

Summary. Coronavirus-like particles are found within the cytoplasm of NPC tumor cells, within the cytoplasm of the tumor cells of the regional metastases, and within tumor cells grown on nude mice. For the immunologic identification of the coronaviruses, the cultures of human tracheal epithelium (MRC-C) were used and inoculated with a known coronavirus strain. Whereas blood sera from NPC patients $(n=73)$ contain significantly elevated antibody titers against corona viruses, unselected sera from patients without NPC showed a low antibody titer $(n=83)$. Only patients suffering from infectious mononucleosis $(n=40)$ showed a titer pattern similar to that of NPC patients. For demonstration of antigen-antibody reaction within the NPC tumor cell cytoplasm, sera with a high antibody content against coronaviruses deriving from other than NPC patients or anticoronavirus sera from rabbits were used. By indirect immunofluorescence, the NPC tumor cells showed a bright cytoplasmic fluorescence. No fluorescence was seen when tumor cells were exposed to human sera with known low or absent corona antibody titer or to normal rabbit sera. The results indicate that next to a DNA virus infection (EBV), an RNA virus infection (coronavirus) may play a role in NPC as well as in infectious mononucleosis.

Key words: Coronavirus-specific antibodies in sera of NPC and infectious mononucleosis patients - Positive immunofluorescent reaction to coronaviruses within the cytoplasm of NPC tumor cells - Statistical analysis

\section{Introduction}

Up to a few years ago, coronaviruses were still classed with the myxoviruses. Through the investigations of Tyrrell et al. $(1968,1975,1978)$, they could be classified as a virus group of their own. Broad scale investigations by McIntosh $(1969,1970,1974)$, Wyatt et al. (1974), Bridger et al. (1978), and Oshiro (1973) have shown that the viruses of the corona group can be the causative organisms of diverse infectious diseases in man and animals. They cause infectious bronchitis in hens, hepatitis in mice, tracheobronchitis and gastrointestinal diseases in humans, and intestinal diseases in cattle. Cartwright and Lucas (1970) regard the coronaviruses as the infectious agent for a certain form of encephalomyelitis in pigs. Demyelination diseases induced by coronavirus infections were also demonstrated in mice (Herndon et al. 1975) and there is an increasing number of reports that a coronavirus infection also plays a role in multiple sclerosis in man (Tanaka et al. 1976; Burks et al. 1980). Similar to the Epstein-Barr virus, the coronaviruses thus appear to be ubiquitously occurring pathogens which give rise to the most diverse lesion patterns depending on the site of infection. For both virus groups, the Epstein-Barr virus (DNA virus) and the coronavirus (RNA virus), a normal infection of the population is known (Henle et al. 1979; McIntosh 1974). The EBV titer, especially the IgG and IgA component in serum, is significantly raised in patients with infectious 
mononucleosis and in patients with nasopharyngeal carcinoma. The immunoglobulins of the $\mathrm{M}$ group are raised exclusively in acute stages of mononucleosis but not in NPC (Henle et al. 1979; De Schryver et al. 1969, 1972; Hsu et al. 1974).

Arnold et al. (1979a, b, 1980a, b) described inclusions resembling coronaviruses in the cytoplasm of the tumor cells in NPC for the first time. They found identical particles in the tumor cells of NPC in the tumor cells of the metastasis and after transplantation of tumor tissue to nude mice. However, Prasad and Gogusev (1978) found strikingly similar structures in NPC tumor cells, although they were not discussed as coronaviruses. Moses et al. (1968) described similar structures in cultures of lymphoid cells of the blood of patients with infectious mononucleosis.

To clarify immunologically the nature of the inclusions we have performed serum titer determinations in NPC patients, in patients with infectious mononucleosis and in a comparison group. We attempted to demonstrate an antigen-antibody reaction in the cytoplasm of tumor cell smears of NPC using the serum of individuals with a high anticorona titer. As controls, we used an anticorona serum derived from rabbits. Since the virological centers available at present do not carry out any serum determinations for antibody against coronaviruses, we have developed a test model of our own for this purpose.

\section{Materials and Methods}

\section{Experimental Design}

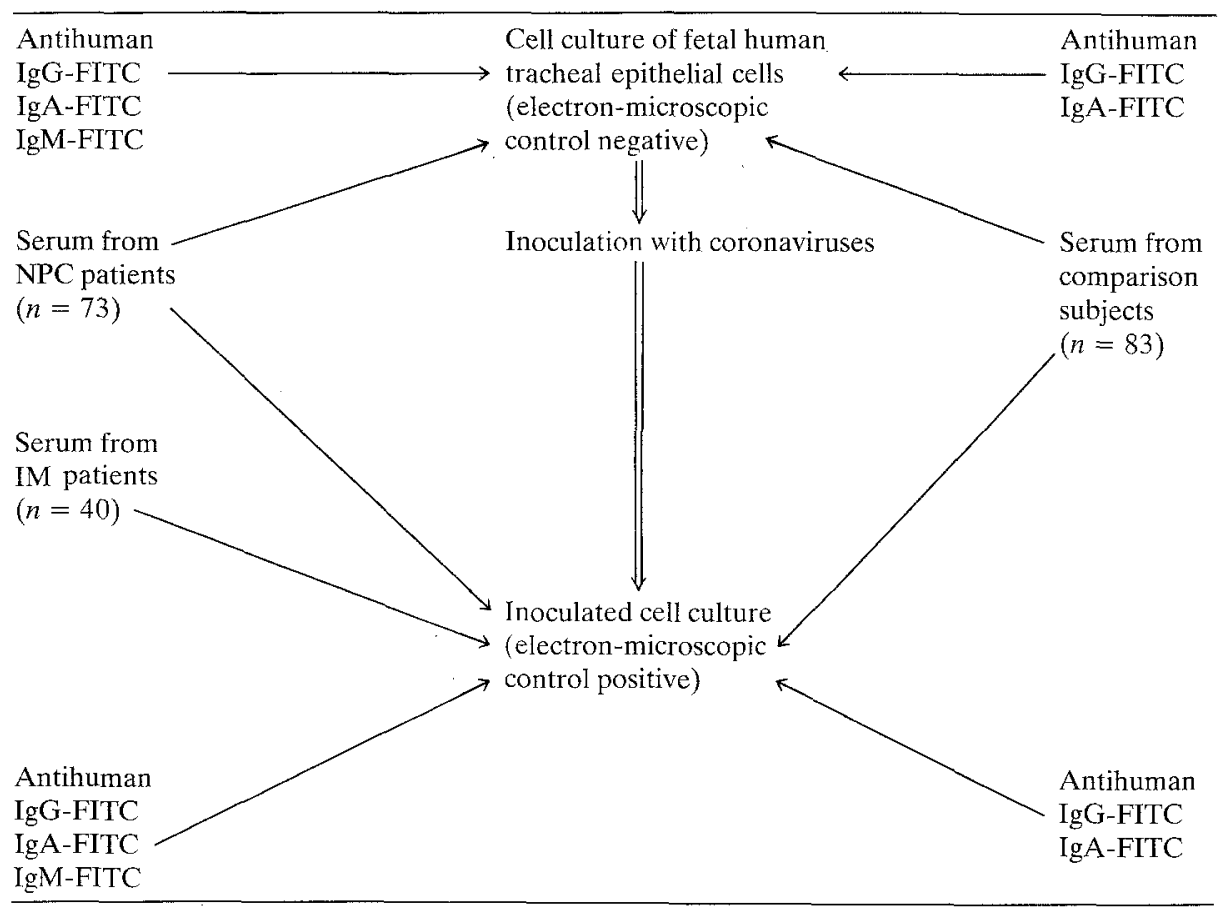


The sera were diluted $1: 10,1: 20,1: 40$, etc. The reaction was read off only up to the dilution at which an unequivocal cytoplasmic fluorescence was still present. The EBV titers of the NPC sera had previously been determined by the laboratories of Prof. zur Hausen (Freiburg) and Dr. Wolf (Munich). The greater part of the sera from NPC patients used in this study was supplied by Prof. zur Hausen and Dr. Wolf. We should like to thank them for their help. The sera from mononucleosis patients derived from the Institute for Medical Microbiology and Virology, University of Düsseldorf. The diagnosis had been made via the demonstration of heterophilic antibodies with the bovine erythyrocyte lysin test (BELT) (Mai 1959).

The sera from the comparison group were taken from blood donors, children with chronic adenotonsillitis, and from patients with tumors outside the nasopharynx.

\section{EBNA Tests}

EBNA were demonstrated on tumor cell smears from nasopharyngeal carcinoma tissues and controlled with the Raji cell test. The EBNA test was carried out on the cells from the cell cultures infected with coronaviruses.

The corona test was carried out on tumor cell smears from nasopharyngeal carcinoma tissues. Cells from the cell culture infected with coronaviruses served as controls. The human sera used in this study were known to have a high anticorona titer. Anticorona rabbit serum was used for control of the reaction.

\section{Statistical Analysis}

Ad 1. The human coronavirus strain $229 \mathrm{E}$ (Medical Research Council, MRC) was cultured on MRC-C cells (permanent human fetal lung fibroblasts). A complete cytopathic effect (CPE) had set in after three days. The cultures were stored at $-70^{\circ} \mathrm{C}$. For the immunofluorescence tests (IFT), uninfected MRC cell suspension with an approximate cell density of $10^{4}$ cells $/ \mathrm{ml}$ was prepared. Of this suspension $100 \mathrm{ml}$ were inoculated with $2 \mathrm{ml}$ of the coronavirus cultures. Afterwards, tissue culture cups were charged with $100 \mu \mathrm{l} / \mathrm{cup}$, sealed under sterile conditions, and incubated for 2 days at $37^{\circ} \mathrm{C}$ until a hint of a CPE became recognizable. After removing the medium, the cultures were air-dried for $15 \mathrm{~min}$ and fixed for $2 \mathrm{~min}$ with methanol at $-70^{\circ} \mathrm{C}$. Methanol residues were removed by two washings with ice-cooled PBS (pH 7.2). The cultures were coated with $10 \%$ glycerol-PBS, placed into the refrigerator for $30 \mathrm{~min}$, and afterwards stored at $-25^{\circ} \mathrm{C}$.

To carry out the immunofluorescence test, the plates were thawed at room temperature, and the glycerol-PBS was eluted. The sera to be tested were diluted with PBS-buffered $0.01 \%$ phenol red solution (in geometrical sequence with the factor 2) to reduce the background and four cups per dilution were charged with $50 \mu \mathrm{l}$. After incubation for $1 \mathrm{~h}$ at $37^{\circ} \mathrm{C}$, the plates were washed three times with the PBS and $50 \mu l$ antihuman IgG-FITC (fluorescein isothiocyanate) from the Company Medac (or antihuman IgA-FITC antihuman IgM-FITC) were added per cup. After incubation for 30 min at room temperature and washing twice, the plates were examined under the fluorescence microscope and the titer determined. In random samples, the coronavirus cultures were investigated under the electron microscope, as well as the noninoculated MRC cultures. At a CPE of $75 \%$, the cells which were still adhering were detached with a scraper, and the cell suspension was centrifuged off for $10 \mathrm{~min}$ at $1,500 \mathrm{rpm}$. The sediment was resuspended in $1 \mathrm{ml}$ ice-cooled $6.25 \%$ glutaraldehyde, centrifuged once more, and the sediment was subjected to the conventional postfixation and embedding procedure for electron microscopy.

Ad 2. Tumor ${ }^{1}$ cell smears of NPC and cell smears of coronavirus-infected MRC cells were fixed in cold absolute methanol $\left(4 \mathrm{~min}, 20^{\circ} \mathrm{C}\right)$ and coated with known EBNA-positive serum $\left(45 \mathrm{~min}, 37^{\circ} \mathrm{C}\right)$. After incubation, which was carried out in a moist chamber, the preparations were washed twice for $5 \mathrm{~min}$ in phosphate-buffered Ringer solution and complement was added $\left(45 \mathrm{~min}, 37^{\circ} \mathrm{C}\right.$ ). After washing once more, the preparations were coated with fluorescein isothiocyanate-conjugated antihuman complement derived from goats (beta I C/beta I A) and incubated as described above. After washing once more, the reaction was evaluated under the fluorescence microscope. All tests included controls with EBV DNA-positive lymphoblastoid Raji cells and with EBV DNA-negative $\mathrm{BJ} A \mathrm{~B}$ cell lines.

1 The EBNA test were kindly performed by A. Nakazima, MD 
For the immunofluorescence-microscopic demonstration of coronaviruses in cell smears, high-titer coronavirus-positive serum which did not derive from NPC patients was used in an analogous way. Furthermore, anti-coronavirus hyperimmune serum deriving from rabbits (diluted 1:300, kindly provided by the Medical Research Council, England) was also used, Coronavirus-negative sera served as controls. High-titer sera and rabbit hyperimmune serum were finally likewise tested on uninoculated MRC cell cultures.

Ad3. Besides the geometric mean, the median was used to describe the data material. The median of a random sample is the value for which both half the measurements are smaller or equal and half the measurements are larger or equal than this value. The median is accordingly the "extreme middle" measurement value.

The geometric mean of a measurement series with the measurement

values $x_{1}, x_{2} \ldots x_{n}$ is given by: $x_{g}=\sqrt[n]{x_{1} \cdot x_{2} \ldots \cdot x_{n}}$.

From $\log x_{g}=1 / n\left(\log x_{1}+\log x_{2}+\ldots+\log x_{n}\right), x_{g}$ can be determined and the standard deviations $s_{\log x g}$ can be calculated.

By back transformation from $\log x_{g} \pm{ }^{s} \log x_{g}$, corresponding limits for $x_{g}$ are obtained. In Table 7 , besides the two measures of location these limits (termed the standard range of the geometric mean) are given.

To test the hypothesis as to whether the titer levels in the three groups (controls, mononucleosis, NPC) are equally distributed, the chi square test was used. The three groups were tested pairwise against each other and titer levels greater than 1:1280 were grouped together in one group (Table 6). To test the hypothesis for equality of the medians, the three groups were compared pairwise with the median test.

Note to Table 7: Use of the geometric mean and its standard deviation which is usual in the literature for construction of a standard range of the mean titer of a population assumes normal distribution of the logarithm of the concentration of the antibodies. Due to the measurement design in stages, only certain values can be measured (in this example, the values jumped by the factor 2 in each case). On the other hand, the medians do not require any assumptions with regard to the distribution of the concentration and hence cannot lead to misinterpretations of the distribution, as is the case for geometric means in this example.

\section{Results}

1. Tables 1 and 2 show the EBV-VCA antibody patterns in a control group and in patients with nasopharyngeal carcinoma. The control group of Table 1 is not identical with the control group of healthy subjects and patients in whom the corona titer (Table 3 ) was determined. Tables 1 and 2 show in a classical way the displacement of the $\operatorname{IgG}$ and $\operatorname{IgA}$ titers to the right in patients with NPC.

2 . Tables 3 shows the distribution of the corona antibody pattern $(\operatorname{IgG}, \operatorname{IgA})$ in a comparison group. In the majority of cases, the sera were from blood donors and from children who had been admitted for adenotonsillectomy. Table 4 reveals a clear shift of the corona IgG titer to the right in NPC patients, whereas

Table 1. Controls (children with chronic nasopharyngeal infections and patients with malignomas other than NPC)

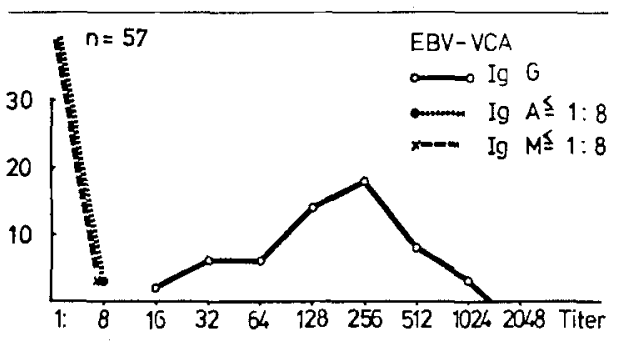


Table 2. NPC

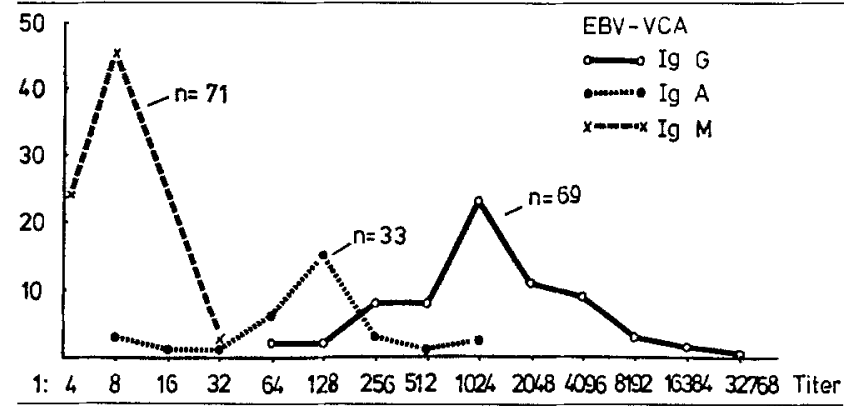

Table 3. Controls (blood donators and patients with malignomas other than NPC)

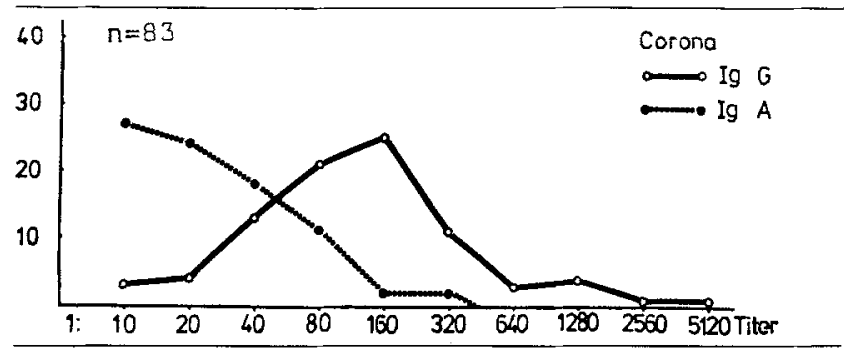

the IgA concentration does not differ compared to the control group. The average IgM level is in the low titer range. It becomes evident from Table 5 that there is no difference with regard to the $\operatorname{IgG}$ titers in serologically verified infectious mononucleosis, but the IgA titers and the IgM titers attain higher values on average. Table 6 shows the individual distribution of the titer levels in the three groups (from Tables $3-5$ ). Table 7 contrasts the geometric mean, the standard range, and the median of the three groups.

3. The EBNA test on the NPC cell smear preparations was always positive (Fig. 1). On the other hand, the EBNA test had a negative result in the cell cultures infected with coronaviruses. The corona test on NPC cell smears always gave rise to a bright positive fluorescence which was exclusively restricted to the cytoplasm irrespective of whether corona hyperimmune serum from rabbits or high-titer "corona" serum from other than NPC patients was used as test serum. If serum from NPC patients was applied to coronavirus infected MRC cell cultures for indirect fluorescence microscopic demonstration of corona-specific antibodies, we found an intense cytoplasmic fluorescence in over $85 \%$ of the tested sera (Fig. $1 \mathrm{a}-\mathrm{b}$ ). On the other hand, if known high-titer "corona" sera are applied to MRC cell lines not infected with corona-viruses, there was no fluorescence.

4. Electron-microscopic investigation of corona-infected MRC cells revealed a lytic destruction of the fibrocytes. Typical coronaviruses were situated preferentially in vacuoles or they were extruded at the cell surface. Their morphological appearance conformed with that of the particles found in the cytoplasm of NPC tumor cells (Figs. 2-4). 
Table 4. NPC

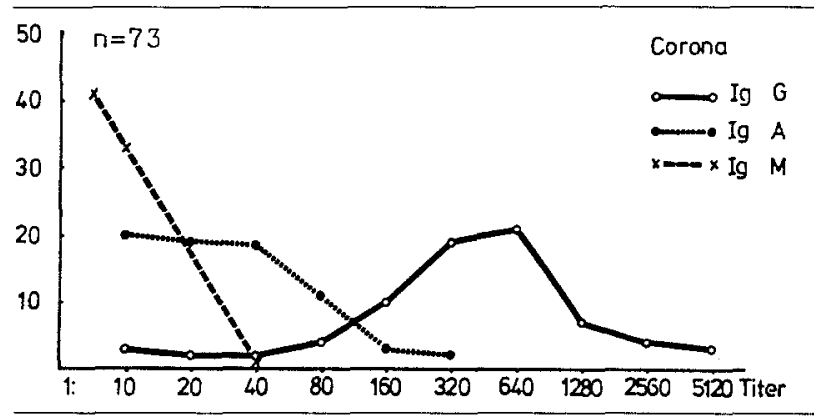

Table 5. Infectious mononucleosis (IM)

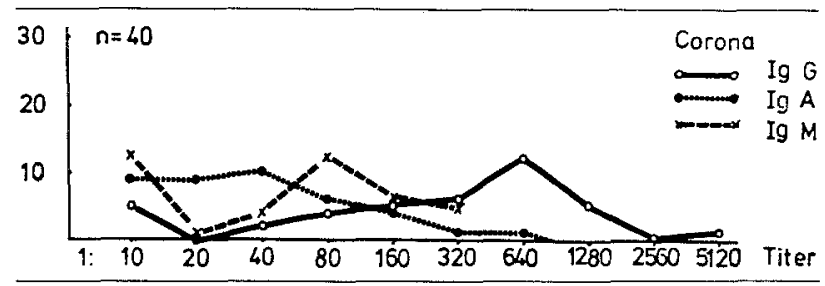

Table 6. Distribution of titer steps in all three groups (absolute quantities)

\begin{tabular}{rccrr}
\hline IgG & Controls & $\begin{array}{l}\text { Infectious } \\
\text { mononucleosis }\end{array}$ & NPC & $n$ \\
\hline 10 & 3 & 5 & 3 & 11 \\
20 & 4 & 0 & 2 & 6 \\
40 & 12 & 2 & 2 & 16 \\
80 & 20 & 4 & 3 & 27 \\
160 & 25 & 5 & 10 & 40 \\
320 & 12 & 6 & 19 & 37 \\
640 & 3 & 12 & 20 & 35 \\
1280 & 4 & 5 & 7 & 16 \\
$>1280$ & 0 & 1 & 7 & 8 \\
$n$ & 83 & 40 & 73 & 196 \\
\hline
\end{tabular}

${ }^{a}$ Significant difference of distribution to controls $\left(\chi^{2}\right.$-test, 8 d.f., $\left.p<0.01\right)$

Table 7. Measures of location and dispersion of the three groups concerning IgG-titer

\begin{tabular}{lllll}
\hline Group & $\begin{array}{l}\text { Number of } \\
\text { cases }\end{array}$ & $\begin{array}{l}\text { Geometric } \\
\text { mean } x_{g}\end{array}$ & $\begin{array}{l}\text { Standard deviation } \\
\text { of } x_{g}\end{array}$ & Median \\
\hline Controls & 83 & $1: 116$ & $1: 104$ to $1: 131$ & $1: 160$ \\
IM & 40 & $1: 234$ & $1: 182$ to $1: 301$ & $1: 320^{\mathrm{a}}$ \\
NPC & 73 & $1: 362$ & $1: 309$ to $1: 424$ & $1: 320^{\mathrm{a}}$ \\
\hline
\end{tabular}

a Significant difference of median to controls (median test, $p<0.01$ )

'See: Material and Methods, Ad 3, "Note to Table 7", see page 169 

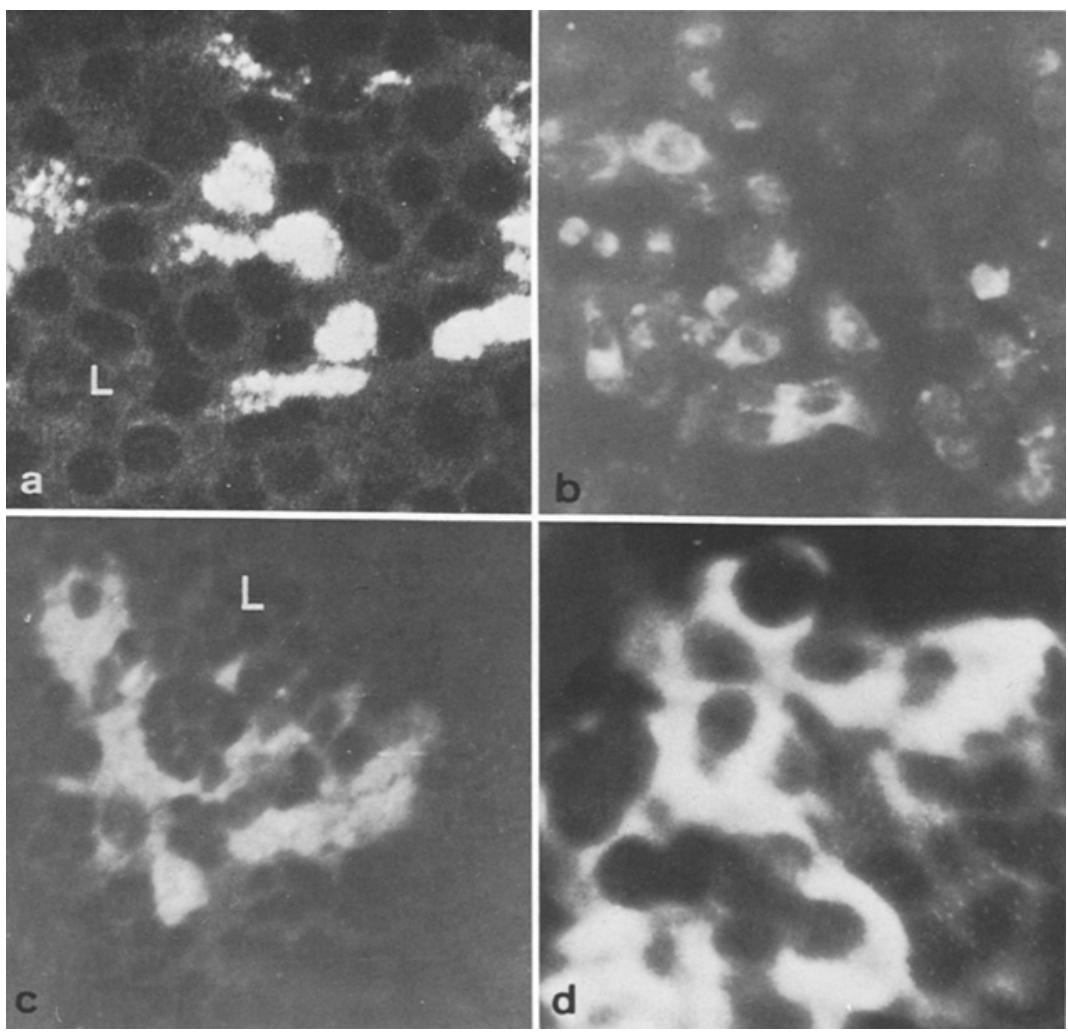

Fig. 1. a NPC-smear preparation: bright granular fluorescence of tumor cell nuclei during EBNA test. Dark holes correspond to lymphocytes (L) b Corona 229E-inoculated MRC culture. Using NPC serum and anti-human IgG-FITC the cytoplasm shows a positive fluorescence whereas the nuclei remain unstained. $\mathbf{c}$ High titer anti-corona serum from a non-NPC patient was added to a NPC-smear preparation together with anti-human IgG-FITC. L-lymphocytes. d NPC-smear preparation. Anti-corona serum derived from rabbits was used and anti-rabbit IgG-FITC was added

Fig. 2. a Coronavirus-like particles within the cytoplasm of a NPC tumor cell $(\nearrow)$. b High magnification $(84,000)$ of corona viruses within the cytoplasm of a metastatic tumor cells. $\nearrow$ Surface projections

Fig. 3. a MRC-culture cell, 3 days after inoculation of corona-229E strain. The degenerating cytoplasm shows multiple vacuoles containing the viruses. $\mathbf{b}$ Different stages of maturation and bud formation $(\lambda)$ 
Fig. 2
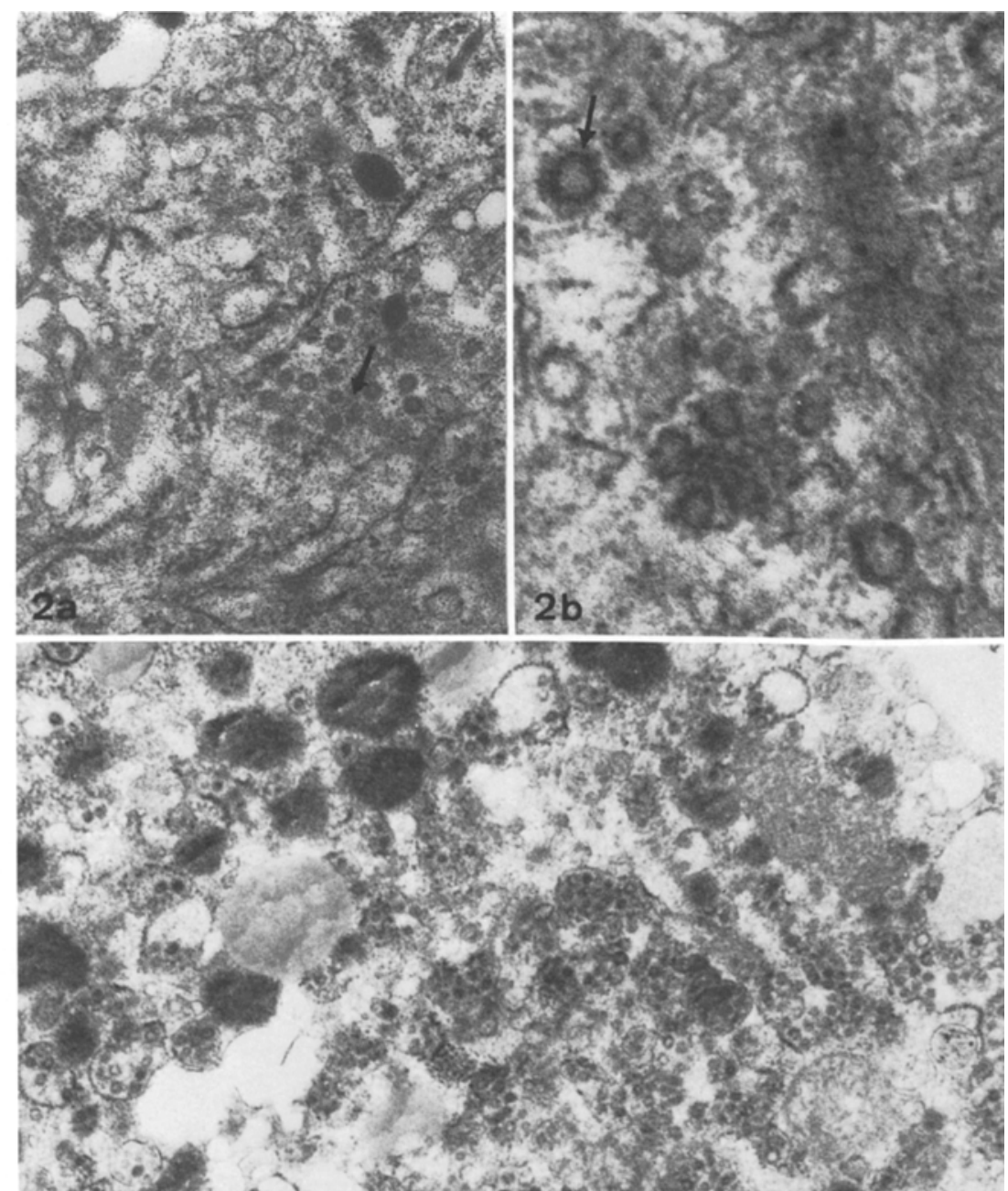

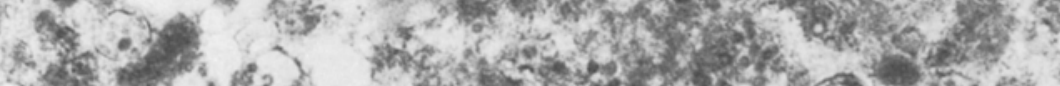
3a

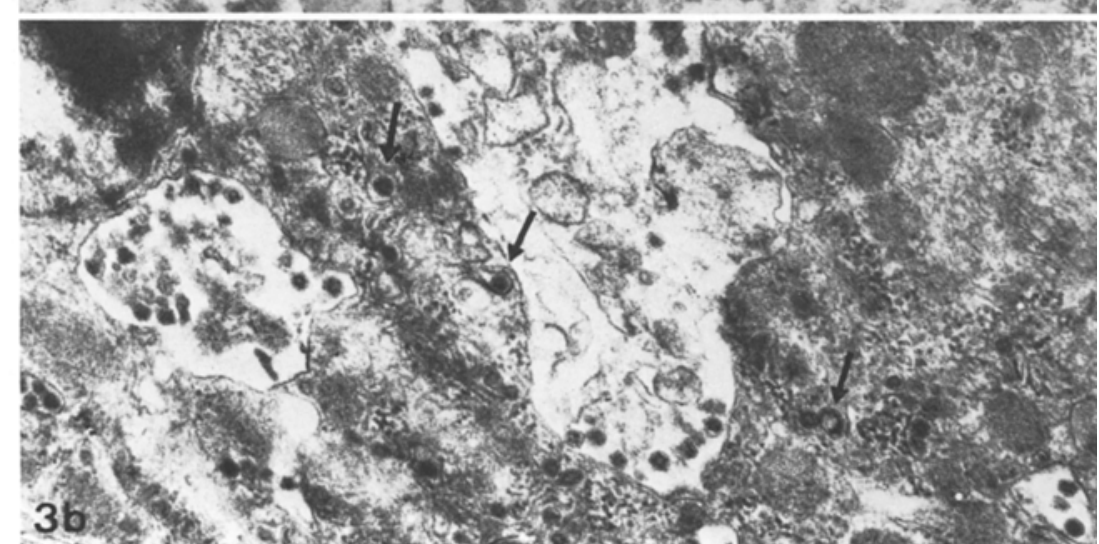

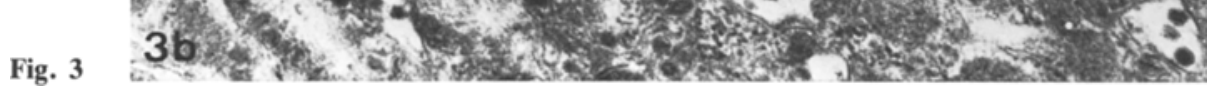




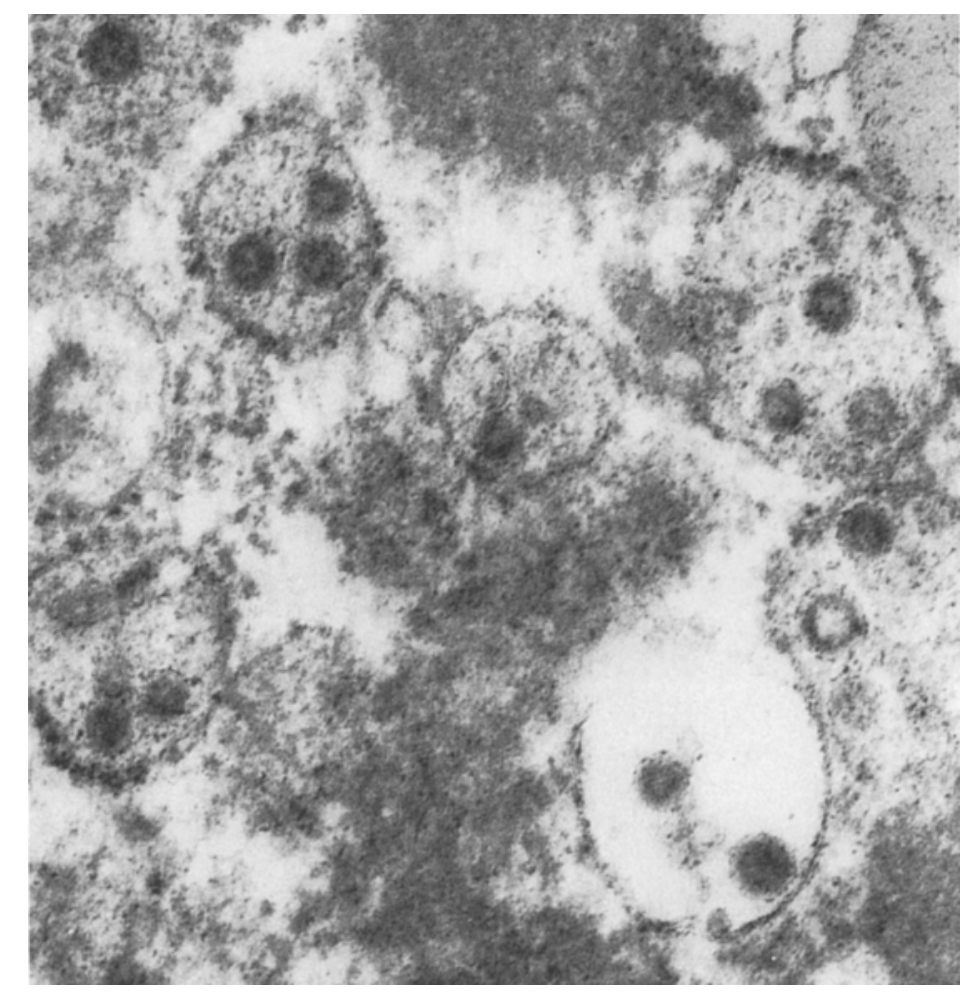

Fig. 4. High magnification $(80,000)$ of cytoplasmic vacuoles and vacuolated endoplasmic reticulum containing viral particles; 24 -h post-infected human diploid lung tissue culture cell (MRC)

\section{Discussion}

The infection of the NPC cell with coronaviruses which we have discussed in earlier communications (Arnold and Huth 1979, 1980; Arnold et al. 1980a, b) were understandably met by justified reservations (Henle, pers. commun. Grundmann, pers. commun.). Exclusively in terms of the morphological appearance, it could not be denied that the particles situated in the cytoplasm of the tumor cells have a similarity with the representative diagrams of coronaviruses reproduced by Oshiro (1973). However, until today not only are corresponding immunologic data lacking, but coronaviruses have also not been isolated from the tumor material nor have coronavirus-specific nucleic acids been demonstrated in NPC tumor tissues.

In our opinion, the demonstration of identical virus particles not only in the tumor cells of the primary tumor, but also in the cells of the metastasis and in the tumor cells of the xenotransplant (Arnold et al. 1980a) fundamentally excluded a possible contamination. On the other hand, the demonstration of coronaviruses in the cytoplasm of tumor cells of the nasopharynx would not be surprising on its own, since patients with extensive tumors of the nasopharynx also suffer from a 
chronic nasopharyngeal infection as a rule. Furthermore, coronaviruses can be demonstrated regularly in the flushing fluids even in healthy subjects after flushing of the nasopharynx (McIntosh et al. 1969, 1974).

In the coronavirus infections known so far, the virus particles were found preferentially in the area of surface epithelia (nasopharyngeal mucosa, tracheal and bronchial mucosa, intestinal mucosa), but could also be isolated from liver tissue in mice. For culturing on culture media, coronaviruses require a choice substrate (tracheal epithelium, Oshiro 1973). Thus, at least the presence of coronaviruses in the tumor cells of the metastasis or of the xenotransplant was surprising and gave rise to further reflections since these viruses evidently become a fixed constituent of the cytoplasm of the metastatic tumor cells of an NPC.

The notion of a growth substrate for coronaviruses restricted to surface epithelia is also disproved by the findings of Cartwright and Lucas (1970), Herndon et al. (1975), Tanaka et al. (1976) as well as Burks et al. (1980): the authors demonstrated coronaviruses within demyelination foci of the CNS and also found coronaviruses in the cerberospinal fluid. Today, coronaviruses are already being discussed as possible etiologic cofactors in multiple sclerosis (Burks et al. 1980).

According to a working hypothesis of Lenoir and DeThé (1978), the epithelial cells of the nasopharyngeal mucosa are postulated to have already undergone damage (possibly exogenously induced) before the subsequent EBV infection leads to the final malignant alteration of cell metabolism. On the basis of the findings of Achong et al. (1971) and Epstein et al. (1974), the infection of the epithelial cells with EB viruses might be mediated by "syncytium-forming viruses which inhabit the respiratory tract" (Lénoir and DeThé 1978). The experimental results of Graffi et al. $(1969,1976,1979)$ indicate the possibility of such an interaction of two different viruses in the malignant transformation of a cell. These authors were able to show that a non-specific RNA virus infection latently present in golden hamsters leads to development of malignancies when a DNA virus infection is superimposed.

The present study has shown that patients with NPC have significantly higher IgG antibody levels against coronaviruses than a control group. A correlation is shown similar to the well-known EBV titer distribution. The evidently close correlation between EBV and coronaviruses also becomes evident from the corresponding results in infectious mononucleosis. Similar to the way in which EBV nuclear antigens can be identified by immunofluorescence microscopy in NPC tumor cells with the EBNA test, corona antigens can be demonstrated in the cytoplasm of tumor cells of the same patient. A possible non-specific reaction could be excluded by use of animal corona antisera.

There must thus be a more than random relationship between the coronavirus infection of NPC tumor cells and the disease "nasopharyngeal carcinoma". This relationship appears to be similar to that of EB viruses to this disease (or also to infectious mononucleosis).

Although it is known that NPC tumor cells contain the viral genome of EB viruses (Andersson-Anvret et al. 1977; zur Hausen 1976), and this virus is not present in healthy nasopharyngeal epithelial cells, they cannot be considered as 
the exclusive pathogenic agent: EBV genomes can also be demonstrated in salivary gland tissue of healthy individuals (Morgan et al. 1979; Wolf and Wilmes 1980).

Further studies are required to clarify whether the tumor cells of NPC contain coronavirus-specific nucleic acids, and whether an interaction of coronaand Epstein-Barr viruses in epithelial cells of a tissue culture is able to induce a malignant transformation.

\section{References}

Achong BG, Mansell PW, Epstein MA (1971) An unusual virus in cultures from a human nasopharyngeal carcinoma. J Natl Cancer Inst 46:299-307

Andersson-Anvret M, Forsby N, Klein G, Henle W (1977) Relationship between the Epstein-Barr virus and undifferentiated nasopharyngeal carcinoma: correlated nucleic acid hybridization and histophathological examination. Int J Cancer 20:486-494

Arnold W, Huth F (1979a) Viren, virusähnliche und auf Viren hinweisende Strukturen beim Karzinom des Nasopharynx. Arch Otorhinolaryngol (NY) 222:295-317

Arnold W, Huth F (1979b) Light- and electron-microscopic investigations of nasopharyngeal carcinomas with regard to the viral etiology of these tumors. J Cancer Res Clin Oncol 94: $87-109$

Arnold W, Huth F, Lindenberger J, Vosteen KH (1980a) Vergleichende Morphologie des lymphoepithelialen Karzinoms: Primärtumor-Metastase-Xenotransplantat. Arch Otorhinolaryngol (NY) 226:15-26

Arnold W, Huth F (1980b) Morphological and immunohistochemical investigations of human NPC before and after transplantation to nude mice. XII. Internat Symp NPC, Oct 23-25, Düsseldorf

Arnold W, Nakazima A, Wang JB, Vosteen KH, Brunner H, Goebel U (1980c) Aktuelle Aspekte zur Ätiologie, Diagnostik und Therapie des Nasenrachenraumkarzinoms (NPC). HNO $28: 247-260$

Bridger JC, Caul EO, Egglestone SI (1978) Replication of an enteric bovine Coronavirus in intestinal organ cultures. Arch Virol 57:43-51

Burks JS, DeVald BL, Jankovsky LD, Gerdes JC (1980) Two coronaviruses isolated from central nervous system tissue of two multiple sclerosis patients. Science 209:933-934

Cartwright SF, Lucas M (1970) Vomiting and wasting disease of piglets. Vet Rec $86: 278-280$

DeSchryver A, Klein G, Henle G, Henle W, Cameron HM, Santesson L, Clifford P (1972) EB-virus associated serology in malignant disease: antibody levels to viral capsid antigens (VCA), membrane antigens (MA) and early antigens (EA) in patients with various neoplastic conditions. Int J Cancer 9:353-364

Epstein MA, Achong BG, Ball G (1974) Further observations on a human syncytial virus from a nasopharyngeal carcinoma. J Natl Cancer Inst 53:681-688

Graffi A, Schramm T, Bender E, Graffi I, Horn KH, Bierwolf D (1968) Cell-free transmissible leukoses in syrian hamsters, probably of viral etiology. Br J Cancer 22:577-581

Graffi A, Bender E, Schramm T, Kuhn W, Schneiders F (1969) Induction of transmissible lymphomas in Syrian hamsters by application of DNA from viral hamster Papovavirus-induced tumors and by cell-free filtrates from human tumors. Proc Natl Acad Sci USA $64: 1172-1175$

Graffi A, Bender E, Schramm T, Graffi I, Niezabitowski A, Schneiders F (1976) Durch ein Oncornavirus induzierte, zellfrei übertragbare Sarkome des Goldhamsters. Arch Geschwulstforsch $46: 77-84$

Graffi A (1979) Zur Ätiologie der Geschwülste. Med Uns Zeit 4:123-131

Henle W, Henle G, Lennette ET (1979) The Epstein-Barr virus. Sci Am 241:40-51

Herndon RM, Griffin DE, McCormick U, Weiner LP (1975) Mouse hepatitis virus-induced recurrent demyelination. Arch Neurol 32:32-35 
Hsu MM, Chiou JF, McCabe BF (1974) Anti-Epstein-Barr virus antibody in nasopharyngeal carcinoma. Ann Otol 83:19-25

Lenoir G, DeThé G (1978) Epstein-Barr virus - epithelial cell interaction and its implication in the etiology of nasopharyngeal carcinoma. In: DeThé G, Ito Y (eds) Nasopharyngeal Carcinoma: Etiology and control. IARC, Lyon, pp 377-384

Mai K (1959) Vorteile eines Rinderblutzellen-Lysin-Testes in der Diagnostik der infektiösen Mononukleose. Zentralbl Bakteriol 176:367-370

McIntosh K, Kapikian AZ, Hardison KH, Hartley JW, Chanock RM (1969) Antigenic relationship among the corona-viruses of man and between human and animal coronaviruses. J Immunol 102: $1109-1118$

McIntosh K, Kapikian AZ, Turner HC, Hartley JW, Parrott RH, Chanock RM (1970) Seroepidemiologic studies of Coronavirus infection in adults and children. Am J Epidemiol 91: $585-592$

McIntosh K (1974) Coronaviruses: A comparative review. Curr Top Microbiol Immunol 63: $85-129$

Morgan DG, Miller G, Niederman IC, Smith HW, Dowaliby IM (1979) Sites of Epstein-Barr virus replication in the oropharynx. Lancet 2:1154-1157

Moses HL, Glade PR, Kasel JA, Rosenthal AS, Hirshaut Y, Chessin LN (1968) Infectious mononucleosis: Detection of herpes-like virus and reticular aggregates of small cytoplasmatic particles in continous lymphoid cell lines derived from peripheral blood. Proc Natl Acad Sci USA $60: 489-496$

Oshiro LS (1973) Coronaviruses. In: Dalton AJ, Haguenau F (eds) Ultrastructure of animal viruses and bacteriophages. Academic Press, New York London, pp 331-343

Prasad U, Gogusev J (1978) Intracisternal tubular inclusions in nasopharyngeal carcinoma. J Laryngol Otol 92:979-989

Tanaka R, Iwasaki Y, Koprowski H (1976) Intracisternal virus-like particles in brain of a multiple sclerosis patient. J Neurol Sci 28:121-126

Tyrrell DAJ, Bynoe ML, Hoorn B (1968) Cultivation of difficult viruses from patient with common colds. Br Med J 1:606-610

Tyrrell DAJ, Almeida JD, Cunningham CH, Dowdle WR, Hofstad MS, McIntosh K, Tajima M, Zakstelskaja LY, Easterday BC, Kapikian A, Bingham RW (1975) Coronaviridae. Intervirology $5: 76-82$

Tyrrell DAJ, Alexander DJ, Almeida JD, Cunningham CH, Easterday BC, Garwes DJ, Hierholzer JC, Kapikian A, MacNaughton MR, McIntosh K (1978) Coronaviridae: Second report. Intervirology $10: 321-328$

Wolf H, Wilmes E (1980) Evidence for the presence of EB-viruses in the parotid gland. Abstr. Herpes Viruses, Cold Spring Harbor, Aug. 1980

Wyatt RG, Kapikian AZ, Thornhill TS, Sereno MM, Kim HW, Chanock RM (1974) In vitro cultivation in human foetal intestinal organ culture of a reovirus-like agent associated with non-bacterial gastroenteritis in infants and children. J Infect Dis 130:523-528

Zur Hausen H (1976) Biochemical approaches to detection of Epstein-Barr virus in human tumors. Cancer Res 36: 678-680

Received January 30, 1981/Accepted February 21, 1981 